\title{
Naturally Occurring Plasmids in Acinetobacter calcoaceticus: a P Class R Factor of Restricted Host Range
}

\author{
By EDWARD HINCHLIFFE AND ALAN VIVIAN \\ School of Biological Sciences, Thames Polytechnic, Wellington Street, London SE18 6PF
}

(Received 14 May 1979)

\begin{abstract}
A naturally occurring transmissible plasmid, designated pAV1, has been isolated in Acinetobacter calcoaceticus. It specifies resistance to sulphonamides and is capable of mobilizing two non-transmissible resistance determinants for tetracycline and neomycin, respectively, within strains of $A$. calcoaceticus. It is incompatible with the $\mathrm{P}$ class $\mathrm{R}$ factors RP4 and R751 in A. calcoaceticus. On this basis we conclude that pAV1 is a member of the $\mathbf{P}$ incompatibility group. However, unlike most other $\mathbf{P}$ group $\mathrm{R}$ factors, pAV1 is not transmissible to strains of Escherichia coli, Pseudomonas aeruginosa, Klebsiella or Proteus mirabilis.
\end{abstract}

\section{INTRODUCTION}

Towner \& Vivian $(1976 a, b)$ have used the plasmid RP4 to mobilize the chromosome in a strain of Acinetobacter calcoaceticus. Using this system of gene transfer and analysis of coinheritance frequencies for markers, a circular linkage map was established for the strain EBF65/65 (Towner, 1978). RP4 mobilizes the chromosome from one of two alternative origins, resulting in a polarized transfer of markers from the donor to the recipient strain. Inheritance of markers distal to both donor origins is rather low, making it difficult to resolve the order of markers in this region of the map (Towner, 1978).

We have continued the search for a more efficient sex factor than RP4 among strains of A. calcoaceticus. In this paper we report the discovery and genetic characterization of a plasmid, designated pAV1, which was obtained from strain $\mathrm{JC17}$, a hospital isolate of A. calcoaceticus. pAV1 apparently has a very restricted host range and for this reason we have found it necessary to perform incompatibility experiments in strain EBF65/65, using $P$ group plasmids, as this is the only group so far shown to transfer to EBF65/65 (Towner \& Vivian, 1977).

\section{METHODS}

Acinetobacter strains and plasmids. These are listed in Table 1 together with their sources. Escherichia coli J53. 2 (Bachmann, 1972) and Pseudomonas aeruginosa OT47 (Loutit et al., 1968) were used for host range experiments, as well as two strains of Proteus mirabilis and two strains of Klebsiella sp. supplied by Dr S. Poston, Guys Hospital Medical School, London.

Media. Minimal medium (MM), Tryptone Soya Agar (TSA) (Towner \& Vivian, 1976a) and basal salts medium (BSM) (Towner, 1978) were used. Minimal medium used for strains other than A. calcoaceticus was that of Vogel \& Bonner (1956), supplemented with glucose at a final concentration of $0.5 \%$ (w/v). Oxoid nutrient agar (NA) was used for some host range experiments, and Oxoid Diagnostic sensitivity test agar was used for antibiotic sensitivity tests.

Determinations of antibiotic sensitivity. These were performed using Oxoid Multodiscs.

Antibiotics. These were obtained from Sigma (except where indicated) and were added to media as freshly prepared solutions at the following final concentrations: sulphadiazine, $500 \mu \mathrm{g} \mathrm{ml}^{-1}$; rifampicin, $100 \mu \mathrm{g}$ $\mathrm{ml}^{-1}$; tetracycline hydrochloride, $5 \mu \mathrm{g} \mathrm{ml}^{-1}$; neomycin sulphate, $50 \mu \mathrm{g} \mathrm{ml}^{-1}$; trimethoprim lactate (Wellcome), $500 \mu \mathrm{g} \mathrm{ml}^{-1}$. 
Table 1. Strains of Acinetobacter calcoaceticus and plasmids

\begin{tabular}{|c|c|c|}
\hline Strains & Relevant characteristics* & Source \\
\hline Bacteria & & \\
\hline $\begin{array}{l}\text { EBF65/65 } \\
\text { EBF65/174 } \\
8250,9299 \\
\text { JC17 } \\
\text { C48 } \\
\text { C426 } \\
\text { C4121 } \\
\text { C4131 } \\
\text { C4145 } \\
\text { C4151 } \\
\text { C4152 } \\
\text { C4156 }\end{array}$ & $\begin{array}{l}\text { Tc Nm Ap Km Su (pAV1) } \\
\text { met-1 ile-1 } \\
\text { trp-2 his-1 } \\
\text { trp-2 his-1 rif-1 } \\
\text { phe-1 thi-2 Tp (R751) } \\
\text { trp-2 his-1 Tc Nm Su (pAV1) } \\
\text { trp-2 his-1 Su (pAV1) } \\
\text { met-1 ile-1 Su (pAV1) } \\
\text { trp-2 his-1 Tc Km Ap (RP4) }\end{array}$ & $\begin{array}{l}\text { Towner \& Vivian }(1976 a) \\
\text { E. M. Barnes, Norwich } \\
\text { National Collection of Industrial Bacteria } \\
\text { J. N. Coetzee, Pretoria, South Africa }\end{array}$ \\
\hline $\begin{array}{l}\text { Plasmids } \\
\text { pAV1 } \\
\text { RP4 } \\
\text { R751 }\end{array}$ & $\begin{array}{l}\text { Su } \\
\text { Tc Km Ap } \\
\text { Tp }\end{array}$ & $\begin{array}{l}\text { This paper } \\
\text { Datta et al. (1971) } \\
\text { Jobanputra \& Datta (1974) }\end{array}$ \\
\hline
\end{tabular}

* Abbreviations (resistance to): Ap, ampicillin; Km, kanamycin; Nm, neomycin; Su, sulphonamides; Tc, tetracycline; Tp, trimethoprim.

Millipore mating technique. The method of Towner \& Vivian (1976b) was used for all quantitative crosses. Replica plate mating. This was done essentially as described by Hopwood et al. (1969). Donor cultures were plated for single colonies on TSA; these single colonies were then replicated to plates of MM plus the appropriate antibiotic, and to plates of TSA evenly spread with $0.1 \mathrm{ml}$ of a recipient culture. After incubation at $28^{\circ} \mathrm{C}$ for $24 \mathrm{~h}$ mating plates were replicated to selective media.

Selection for $R$ factor transfer. Selection was made by Millipore mating between JC17 and C4121 and plating on BSM supplemented with $\mathrm{D}(-)$-mandelic acid (Sigma) at a final concentration of $5 \mathrm{mM}$. This selection was necessary because of the relatively high mutation rate to rifampicin resistance and $D(-)$ mandelate utilization in JC17. We were unable to select directly for pAV1 transfer by this method, since no transconjugants were obtained that were resistant to both rifampicin and sulphonamides.

Stability of plasmids. This was determined as described by Towner \& Vivian (1976 b).

Incompatibility studies with pAV1. These were done in A. calcoaceticus EBF65/65 with the plasmids RP4 and R751, using the Millipore mating technique. Transconjugants were streaked on TSA and replicated to check for the inheritance of resistance markers. The stability of clones carrying resistance markers of two different plasmids was determined as described by Datta \& Hedges (1971).

Host range of pAV1. This was determined by the Millipore mating technique. Filters were additionally incubated on NA at $37^{\circ} \mathrm{C}$ in all crosses involving recipient strains other than $A$. calcoaceticus.

\section{RESULTS}

\section{Transfer of resistance determinants}

Strain $\mathrm{JC17}$ is one of a collection of Acinetobacter cultures originally isolated from patients in a hospital in Pretoria, South Africa. Many of these strains show multiple drug resistance; $\mathrm{JC} 17$ is resistant to tetracycline, sulphonamides, neomycin, kanamycin and ampicillin, and is unable to utilize $\mathrm{D}(-)$-mandelic acid as a carbon source. Strain EBF65/65 and its derivatives are able to utilize $\mathrm{D}(-)$-mandelic acid as a carbon source and are also resistant to kanamycin and ampicillin. For the reasons indicated in Methods, it was only possible to select for transfer of tetracycline resistance into strain EBF65/65. Tetracyclineresistant transconjugants were obtained in strain C4121 at a frequency of $4.0 \times 10^{-6}$ per recipient cell. Examination of these transconjugants showed that most were also resistant to neomycin, and a small proportion (11 in 400) were also resistant to sulphonamides.

Subsequent replica plate mating of a sample of 49 transconjugants with the recipient strain C48 indicated that only 11, all of which had acquired sulphonamide resistance, were 
Table 2. Frequency of $R$ factor transfer in auxotrophic strains of $A$. calcoaceticus EBF65/65

\begin{tabular}{|c|c|c|c|c|c|}
\hline Donor & Recipient & $\begin{array}{l}\text { Resistance } \\
\text { marker* } \\
\text { selected } \\
\text { from donor }\end{array}$ & $\begin{array}{c}\text { Resistance } \\
\text { marker* } \\
\text { unselected } \\
\text { from donor }\end{array}$ & $\begin{array}{l}\text { Frequency of } \\
\text { transfer (Su } \mathrm{R}^{+} \\
\text {transconjugants } \\
\text { per recipient) }\end{array}$ & $\begin{array}{l}\text { Characteristics of } \\
\text { transconjugants* }\end{array}$ \\
\hline C4151 & $\mathrm{C} 48$ & $\mathrm{Su}$ & - & $2.0 \times 10^{-1}$ & \\
\hline $\mathrm{C} 4152$ & C426 & $\mathrm{Su}$ & - & $2.0 \times 10^{-1}$ & \\
\hline \multirow[t]{4}{*}{$\mathrm{C} 4145$} & $\mathrm{C} 48$ & $\mathrm{Su}$ & - & $2.0 \times 10^{-1}$ & $305(1500) \mathrm{Tc}^{\mathrm{R}} \mathrm{Nm}^{\mathrm{R}}$ \\
\hline & & Tc & $\mathrm{Su}$ & $6.4 \times 10^{-2}$ & \\
\hline & & $\mathrm{Tc}$ & $一$ & $6.4 \times 10^{-2} \dagger$ & $543(547) \mathrm{Su}^{\mathrm{R}}$ \\
\hline & & $\mathrm{Nm}$ & - & $4.8 \times 10^{-2} \dagger$ & $359(366) \mathrm{Su}^{\mathrm{R}}$ \\
\hline
\end{tabular}

* Nm, neomycin; Tc, tetracycline; Su, sulphonamides.

$\dagger$ Frequency of transfer expressed as Tc and $\mathrm{Nm} \mathrm{R}^{+}$transconjugants, respectively, per recipient.

$\ddagger$ Numbers in parentheses indicate the total number of colonies tested.

Table 3. Incompatibility properties of plasmids in EBF65/65

\begin{tabular}{|c|c|c|c|c|}
\hline Donor & Recipient & $\begin{array}{l}\text { Selected } \\
\text { plasmid } \\
\text { resistance* }\end{array}$ & $\begin{array}{l}\text { Frequency of } \\
\mathrm{R} \text { factor } \\
\text { transfer } \dagger\end{array}$ & $\begin{array}{l}\text { Characteristics of } \\
\text { transconjugants* } \ddagger\end{array}$ \\
\hline C4152(pAV1) & C4156(RP4) & $\mathrm{Su}$ & $1.3 \times 10^{-2}$ & $\begin{array}{r}137(137) \mathrm{Su}^{\mathrm{R}} \mathrm{Tc}^{\mathrm{S}} \\
(\mathrm{RP} 4 \text { eliminated) }\end{array}$ \\
\hline C4152(pAV1) & C4131(R751) & $\mathrm{Su}$ & $1.4 \times 10^{-2}$ & $\begin{array}{l}80(80) \mathrm{Su}^{R} \mathrm{Tp}^{\mathrm{S}} \\
\left(\mathrm{R} 751 \text { eliminated }^{2}\right.\end{array}$ \\
\hline C4156(RP4) & $\mathrm{C} 4152(\mathrm{pAV} 1)$ & $\mathrm{Tc}$ & $7 \cdot 3 \times 10^{-2}$ & $\begin{array}{c}522(524) \mathrm{Tc}^{\mathrm{R}} \mathrm{Su}^{\mathrm{R}} \\
(\mathrm{pAV1} \text { retained) }\end{array}$ \\
\hline C4131(R751) & C4152(pAV1) & Tp & $8.0 \times 10^{-3}$ & $\begin{array}{c}165(166) \mathrm{Tp}^{R} \mathrm{Su}^{\mathrm{R}} \\
(\mathrm{pAV1} \text { retained })\end{array}$ \\
\hline C4156(RP4) & C4131(R751) & $\mathrm{Tc}$ & $5.6 \times 10^{-4}$ & $\begin{array}{l}246(246) \mathrm{Tc}^{\mathrm{R}} \mathrm{Tp} \mathrm{p}^{\mathrm{s}} \\
\text { (R751 eliminated) }\end{array}$ \\
\hline C4131(R751) & C4156(RP4) & $\mathrm{Tp}$ & $3 \cdot 8 \times 10^{-3}$ & $\begin{array}{r}208(208) \mathrm{Tp}^{\mathrm{R}} \mathrm{Tc}^{\mathrm{S}} \\
\text { (RP4 eliminated) }\end{array}$ \\
\hline C4156(RP4) & $\mathrm{C} 48$ & $\mathrm{Tc}$ & $8.7 \times 10^{-4}$ & \\
\hline C4131(R751) & $\mathrm{C} 48$ & Tp & $1.0 \times 10^{-2}$ & \\
\hline
\end{tabular}

able to mediate further transfer of either tetracycline, neomycin or sulphonamide resistance. Millipore matings between C4145 and C48 resulted in the segregation of the sulphonamide resistance determinant from the tetracycline and neomycin resistance determinants amongst the transconjugants (Table 2). Segregation of neomycin and tetracycline determinants from each other was not observed in crosses of this type. Consequently it was concluded that the sulphonamide resistance determinant is associated with a self-transmissible plasmid, designated pAV1. Two other resistance determinants are associated with resistance to tetracycline and neomycin, respectively; neither is self-transmissible in EBF65/65. It is not clear at this stage whether these two determinants constitute a single replicon (E. Hinchliffe, A. Vivian \& R. W. Hedges, unpublished results).

Millipore matings with transconjugants carrying pAV1 showed that it was transferred at much higher frequencies within derivatives of EBF65/65, whether selection was made directly for sulphonamide resistance or indirectly for tetracycline resistance (Table 2). 
Table 4. Stability of $R$ factors in pairs in A. calcoaceticus EBF65/65

\begin{tabular}{|c|c|c|c|c|c|}
\hline \multirow[b]{2}{*}{ Strain } & \multirow{2}{*}{$\begin{array}{l}\text { Resistance } \\
\text { markers* }\end{array}$} & \multirow{2}{*}{$\begin{array}{l}\text { No. of } \\
\text { colonies } \\
\text { tested }\end{array}$} & \multicolumn{3}{|c|}{$\begin{array}{l}\text { No. of colonies that did not } \\
\text { grow on plates containing*: }\end{array}$} \\
\hline & & & $\mathrm{Su}$ & $\mathrm{Tp}$ & $\mathrm{Tc}$ \\
\hline C4152(pAV1)RP4 ${ }^{+}$ & $\mathrm{Su}, \mathrm{Tc}$ & 1587 & 3 & - & 1564 \\
\hline C4152(pAV1)R751 ${ }^{+}$ & $\mathrm{Su}, \mathrm{Tp}$ & 1043 & 3 & 1043 & - \\
\hline
\end{tabular}

\section{Properties of $\mathrm{pAV} 1$}

Stability in strain EBF65/65. pAV1 is very stable in strain EBF65/65. A sample of 1247 colonies cultured on antibiotic-free media retained sulphonamide resistance and sex-factor activity in 1243 colonies. Sex-factor activity was always associated with sulphonamide resistance, as indicated by mobilization of the non-transmissible resistance determinants.

Host range. pAV1 was unable to transfer itself at any detectable frequency $\left(<1 \times 10^{-8} \mathrm{R}^{+}\right.$ transconjugants per recipient) to other species of Gram-negative bacteria tested. These included the strains of Klebsiella, Proteus mirabilis, Pseudomonas aeruginosa and E. coli listed in Methods. pAV1 did not transfer to any of the other wild-type strains of $A$. calcoaceticus listed in Table 1.

Incompatibility studies. Crosses were made between appropriately marked strains carrying one of the plasmids pAV1, RP4 or R751 so that all pairwise combinations of plasmids could be tested (Table 3 ). The mating mixtures were plated on media selecting for reciprocal transfer of resistance markers between parent strains, and the phenotypes of the resulting transconjugants were tested by replica plating to appropriate drug-supplemented media. Transfer between $\mathrm{pAV1}{ }^{+}$recipients and either $\mathrm{RP}^{+}$or $\mathrm{R} 751^{+}$donor strains occurred at a relatively high frequency, without apparent evidence of entry exclusion. However, the reciprocal transfer of PAV1 was slightly reduced (approximately 10-fold) by RP4 or R751 in the recipient. RP4 in the recipient did not exhibit strong entry exclusion of R751, unlike the case in $E$. coli $\mathrm{K} 12$ where there is an approximately 1000 -fold reduction in the transfer of R751 (Hedges \& Jacob, 1974). Further, whenever selection was made for the transfer of pAV1 into an $R^{+}$strain, there was a concomitant displacement of the resident plasmid; this was also true for crosses between R751 and RP4 and has been described for crosses involving R906 (Hedges et al., 1974) and for RP4 and R751 (Hedges \& Jacob, 1974). However, when selection was made for the transfer of a $\mathrm{P}$ class $\mathrm{R}$ factor into a pAV1+ strain, only a very small proportion of transconjugants showed sulphonamide sensitivity. Transconjugant colonies selected for tetracycline resistance from the cross involving RP4 and pAV1 were found to be of two different sizes. Large colonies carried resistance to tetracycline alone, whereas smaller colonies invariably were resistant to both tetracycline and sulphonamide, and it was therefore concluded that they carried both RP4 and pAV1.

The stability of pairs of plasmids amongst transconjugants was tested by subculturing and replicating to check for the continued presence of both $\mathbf{R}$ factors. The results suggested that co-existence of pAV1 with either RP4 or R751 did not persist for more than a few generations, and the plasmid retained was always pAV1 (Tables 3 and 4). A similar preferential retention of plasmid $\mathrm{R} 772$ over $\mathrm{R} 751$ in $E$. coli $\mathrm{K} 12$ has recently been described by Coetzee et al. (1979).

\section{DISCUSSION}

The evidence presented in this paper indicates that a self-transmissible plasmid specifying resistance to sulphonamides has been transferred from a hospital isolate of $A$. calcoaceticus into the genetically mapped strain EBF65/65. This plasmid, designated pAV1, is unusual in 
that it appears to be a member of the $\mathrm{P}$ incompatibility group of $E$. coli, but is restricted to certain strains of $A$. calcoaceticus in its host range.

There is no significantly large reduction in reciprocal resistance transfer between the $\mathrm{P}$ class plasmids and pAVI, unlike the situation described for the I and N group of plasmids (Datta \& Hedges, 1971), and the P group R factors RP4, R751 and R906 (Hedges \& Jacob, 1974; Hedges et al., 1974). The frequencies of reciprocal resistance transfer involving pAV1 (Table 3) are 10- to 100-fold higher than those involving RP4 and R751 alone. This enhanced frequency of transfer of RP4 and R751 may be due to less fragile conjugal unions in which pAVI is involved, or alternatively pAVI-mediated mobilization following superinfection by this more efficient $\mathrm{R}$ factor.

The displacement of RP4 and R751 by pAV1 under non-selective conditions (Table 4) is good evidence that pAVl is a member of the $\mathbf{P}$ incompatibility group of plasmids (Novick et al., 1976). Further evidence in support of this thesis is the formation of large and small transconjugant colonies in crosses involving RP4 and pAV1, when selected as tetracyclineresistant. We attribute this phenomenon to a small proportion of cells carrying RP4 in a colony which is predominantly $\mathrm{pAVI}^{+}$. Consequently these few cells confer residual tetracycline resistance on their parent colony. Datta \& Hedges (1971) showed that the plasmid most frequently retained in stability studies of this kind is the one whose resistance marker is selected in the cross. In contrast, pAV 1 may be retained in preference to RP4 and R751, because it has a much higher affinity for the $A$. calcoaceticus host. One might expect this result if pAV1 is a true naturally occurring Acinetobacter sex factor.

Unlike other members of the P incompatibility group of plasmids, pAV1 has a limited host range (Datta et al., 1971; Datta \& Hedges, 1972; Olsen \& Shipley, 1973), although Terakado \& Mitsuhashi (1974) have reported a narrowed host range for the P class plasmid Rte 6 alias R906 (Hedges et al., 1974), isolated from Bordetella bronchiseptica. The inability of pAVI to transfer to other Gram-negative bacteria may be limited by the intrinsic incompatibility of plasmid-specified donor structures and recipient sites. Alternatively stable $\mathrm{pAV}^{+}$recipient formation may be limited by the inability of pAV1 to replicate in a foreign host. Whichever alternative is true, our findings may be indicative of some degree of specialization amongst members of the P-1 incompatibility group.

It is obviously of interest to investigate the relationship between the plasmid pAVI, described here, and the non-transmissible tetracycline and neomycin resistance determinants, since this might shed some light on the importance of relatively non-pathogenic bacteria in the spread of antibiotic resistance.

We would like to thank all those who have donated bacterial strains, especially Dr S. Poston. We are very grateful to Dr R. W. Hedges and Dr P. H. Williams for their helpful advice and encouragement and to $\mathrm{Mr} \mathrm{A}$. P. Kelly for his technical assistance.

\section{REFERENCES}

Bachmann, B. J. (1972). Pedigrees of some mutant strains of Escherichia coli K12. Bacteriological Reviews 36, 525-557.

Coetzee, J. N., lecatsas, G., Coetzee, W. F. \& Hedges, R. W. (1979). Properties of R plasmid R772 and the corresponding pilus-specific phage PR772. Journal of General Microbiology 110, 263-273.

Datta, N. \& Hedges, R. W. (1971). Compatibility groups among $\mathrm{fi}^{-} \mathrm{R}$ factors. Nature, London $\mathbf{2 3 4}$, 222-223.

Datta, N. \& Hedges, R. W. (1972). Host ranges of $\mathrm{R}$ factors. Journal of General Microbiolog. 70 , $453-460$.

Datta, N., Hedges, R. W., Shaw, E. J., Sykes, R. B. \& Richmond, M. H. (1971). Properties of an $\mathrm{R}$ factor from Pseudomonas aeruginosa. Journal of Bacteriology 108, 1244-1249.

Hedges, R. W. \& JACOB, A. E. (1974). Transposition of ampicillin resistance from RP4 to other replicons. Molecular and General Genetics 132, 31-40.

Hedges, R. W., Jacob, A. E. \& Smith, J. T. (1974). Properties of an $\mathrm{R}$ factor from Bordetella bronchiseptica. Journcil of General Microbiology 84, 199. 204.

Hopwood, D. A., Harold, R. J., Vivian, A. \& FERGuson, H. M. (1969). A new kind of fertility 
variant in Streptomyces coelicolor. Genetics 62, $461-477$.

Jobanputra, R. S. \& DatTa, N. (1974). Trimethoprim resistance factors in enterobacteria from clinical specimens. Journal of Medical Microbiology 7, 169-177.

Loutit, J. S., Pearce, L. E. \& Marinus, M. G. (1968). Investigation of the mating system of Pseudomonas aeruginosa strain 1. Genetical Research 12, 29-36.

Novick, R. P., Clowes, R. C., Cohen, S. N., Curtiss III, R., Datta, N. \& Falkow, S. (1976). Uniform nomenclature of bacterial plasmids: a proposal. Bacteriological Reviews 40, 168-189.

OlSEN, R. H. \& SHIPLEY, P. (1973). Host ranges and properties of the Pseudomonas aeruginosa $\mathrm{R}$ factor R1822. Journal of Bacteriology 113, 772-780.

Terakado, N. \& Mitsuhashi, S. (1974). Properties of $\mathbf{R}$ factors from Bordetella bronchiseptica. Antimicrobial Agents and Chemotherapy 6, 836-840.
TOWNER, K. J. (1978). Chromosome mapping in Acinetobacter calcoaceticus. Journal of General Microbiology 104, 175-180.

TOWNER, K. J. \& VIVIAN, A. (1976a). RP4-mediated conjugation in Acinetobacter calcoaceticus. Journal of General Microbiology 93, 355-360.

TOWNER, K. J. \& ViviaN, A. (1976b). RP4 fertility variants in Acinetobacter calcoaceticus. Genetical Research 28, 301-306.

Towner, K. J. \& Vivian, A. (1977). Plasmids capable of transfer and chromosome mobilization in Acinetobacter calcoaceticus. Journal of General Microbiology 101, 167-171.

VoGel, H. J. \& BonNeR, D. M. (1956). Acetylornithinase of Escherichia coli: partial purification and some properties. Journal of Biological Chemistry 218, 97-106. 